\title{
Determining Factors Influencing Faculty Feedback using Data Mining Technique
}

\author{
Monika Gupta Vashisht, Ashima Kalra, Bhawna
}

\begin{abstract}
Faculty is a major stakeholder in an education institute. Quality of faculty reflects the quality of youth, the future nation builders. Based on the vision of honorable management, an attempt has been made to gather the feedback of faculty reflecting their current state of work. Data have been collected initially via open-ended questionnaire. Faculties serving renowned institutes in the states of Punjab and Haryana have been approached to gather information. Attributes have been identified from the literature review and using an appropriate measurement scale. Only the willing respondents and their responses have been taken into consideration. The responses gathered using 5-point Likert-Scale was then factor analyzed. The attributes converged mainly on six dimensions- recognition, sense of belongingness, working environment, basic need fulfillment, self-respect, and contribution to society. These dimensions have been discussed keeping in view the current scenario in the education sector. The study also provides insights into future research.
\end{abstract}

Index Terms: Faculty, Higher Education, Factor Analysis and Satisfaction

\section{INTRODUCTION}

Highlight a section that you want to designate with a certain style, and then select the appropriate name on the style menu. The style will adjust your fonts and line spacing. Do not change the font sizes or line spacing to squeeze more text into a limited number of pages. Use italics for emphasis; do not underline.

As per well-regarded QS World University Rankings for 2019, only six Indian Institutes of Technology (IITs) and the Indian Institute of Science (IISc), Bengaluru succeeded in fetching ranking among the top 400 universities (M, Ahmad, University World News, 08 February 2019). The major areas of concern are quality of teaching and research, the pressure to publish, leadership, quality of student intake, and faculty-student ratio. Quality of faculty, as well as students, is the clear reflection of teaching and research in any university or institute.

The Indian government is promoting higher education by creating awareness among youth belonging to various sections in the society. With 36.64 million student enrollment for higher education in 39,050 colleges and 903 universities in India in 2017-18, the Gross Enrolment Ratio in higher education reached 25.8 percent in 2017-18 (India Brand Equity Foundation Report, April 2019). The private sector is equally taking interest in investing in the Indian education

Revised Manuscript Received on June 15, 2019.

Dr. Monika Gupta Vashisht, CBSA, CGC Landran, India.

Dr. Bhawna, CEC, CGC Landran India.

Ms. Ashima Kalra, CEC, CGC Landran India. sector. As a result, the share of the state private universities as part of total universities increased from 3.43 percent in 2008-09 to 34.82 percent as of April 2018. At present, there are 384 state universities, 123 deemed to be universities, 47 central universities, and 296 private universities in India. Still there exists an additional requirement of two lakhs schools, thirty five thousand colleges, seven hundred universities and forty million seats in the vocational training centers.

Teachers are the pillars of our nation. 'Mentor India' campaign launched by Niti Aayog in August 2017 (India Brand Equity Foundation Report, June 2018). Keeping this in view, institutions have been taking feedback from their faculty to identify the factors on the basis of which appropriate and timely action may be taken to take necessary action contributing to faculty satisfaction.

The Objective of the study

The objective of the study undertaken is:

"To determine how various factors rate on faculty evaluation towards satisfaction for imparting better higher education".

\section{REVIEW OF LITERATURE}

C. M. Calkins (2018) explored faculty motivation to teach via the theoretical framework of teacher efficacy, achievement goals, and task values. The researcher also employed constructs of work life, satisfaction, and perceptions of student motivation. It has been observed that factors such as perceptions of student motivation had a positive impact on motivation to teach, whereas factors such as research requirements had a negative impact on motivation to teach. V. Ramachandran, M. Pal, Dr. S. Jain, S. Shekar, J. Sharma (2005) proposed a study on teacher motivation in India. They reviewed secondary data such as published material on India, policy documents and government data They collected primary data by surveying schools in Tonk District, Rajasthan. They also interviewed stakeholders in Rajasthan. They observed that motivating teachers is highly complex owing to the lack of incentive for teachers who put in extra efforts beyond duty hours and give liberty to students to learn and succeed in life. The more depressing fact is teachers with political connections and links with local bureaucrats are getting benefitted in terms of suitable postings and teachers' awards. Z. Ozguner and M. Ozguner (June 2014) conducted literature research with the aim to investigate the relationship between Maslow's hierarchy of needs, and Herzberg's dual factor theory. M. I. 
Rasheed, A. A. Humayon, U. Awan and A-ud-D. Ahmed (2016) explored various issues of teachers' motivation by conducting surveys and interviews in the well known public sector higher education universities in Pakistan. They found factors like job design, performance management system, working environment, and training and development are also of high significance besides monetary incentives and compensation packages. S. Munyengabe, H. Haiyan, Z. Yiyi and S. Jiefei (2017) aimed to correlate and investigate the levels and factors affecting lecturers' motivation and job satisfaction in the university located in Beijing, China. They found the motivational level of lecturers satisfactory, resting on Incentives \& promotions and salary. The job satisfaction level was affected by financial reward. They found a significant correlation relationship between lecturers' motivation and job satisfaction. World Development Report (2018) also stated that teachers must teach effectively for making students learn. For this, we must focus on motivating teachers and teachers' skills. J. Han and H. Yin (2016) identified research areas with reference to teacher motivation. Accordingly, they proposed directions for future research, which formed the basis of study undertaken.

\section{RESEARCH METHODOLOGY}

The research has been conducted based on the view of finding the realistic factors influencing feedback of faculty teaching in higher educational institutions. For this, faculty members teaching in various programs in higher education have been asked to mention their expectations from the college via an open-ended questionnaire. Qualitative analysis of this data helped to determine the extent to which the empirical items adequately capture college faculty members' feedback, leading to their salient motivations. Also, literature has been reviewed and attributes contributing to faculty feedback have been identified. The researchers approached faculty members based on their convenience and judgment. Government initiatives at various levels have also been referred.

Measures: The major focus of the study is finding the major factors impacting higher education institutions' faculty. The questions related to respondents demographics were based on research conducted by H. U. Amin and A. R. Khan (2009). The instrument that was used to determine the teachers' motivational needs was prepared based on the scales developed by Shoura and Singh (1998) and Everard and Morris (1996), mentioned in the research conducted by F. Gokce (2010). The scale consisted of 29 items, with high reliability, and more predictive validity.

\begin{tabular}{|l|l|}
\hline & Statements \\
\hline 1 & $\begin{array}{l}\text { I have a job in which I can easily meet all my physiological needs } \\
\text { water, etc. })\end{array}$ \\
\hline 2 & $\begin{array}{l}\text { The institution where I work is not exposed to any danger that } \\
\text { cause health problems. }\end{array}$ \\
\hline 3 & I have job security at the institution where I work. \\
\hline 4 & My superiors do not try to block my advancement. \\
\hline 5 & My peers do not try to damage my career. \\
\hline 6 & I have lots of friends at the institution where I work. \\
\hline 7 & The institution where I work contributes to my recognition. \\
\hline 8 & My peers help each other in the workplace. \\
\hline
\end{tabular}

\begin{tabular}{|c|c|}
\hline 9 & I respect myself for having the profession of teaching. \\
\hline 10 & People respect me because I am a teacher. \\
\hline 11 & $\begin{array}{l}\text { I am popular in my institution because of my professional } \\
\text { and competence. }\end{array}$ \\
\hline 12 & I feel at home in the workplace. \\
\hline 13 & I consider myself equipped for teaching. \\
\hline 14 & $\begin{array}{l}\text { The institution where I work provides me with sufficient resources } \\
\text { do my job better. }\end{array}$ \\
\hline 15 & Teaching is an ideal job for me. \\
\hline 16 & I can use my creativity in the institution where I work. \\
\hline 17 & Teaching makes my life more meaningful. \\
\hline 18 & My job gives me freedom and power. \\
\hline 19 & My job contributes to the development of society and the state. \\
\hline 20 & I have a job which is in harmony with the expectations of people. \\
\hline 21 & I have opportunities to broaden my professional knowledge. \\
\hline 22 & I think I am doing my job properly. \\
\hline 23 & The people in my institution know me as a successful worker. \\
\hline 24 & The institution where I work aids continuous learning. \\
\hline 25 & $\begin{array}{l}\text { My institution gives me the opportunity to know whether I do my } \\
\text { well or not. }\end{array}$ \\
\hline 26 & I hear new ideas in the institution where I work. \\
\hline 27 & I have a job which helps me to achieve my goals in life. \\
\hline 28 & My institution gives a quality education based on learning. \\
\hline 29 & $\begin{array}{l}\text { My institution adopts a democratic and participatory approach } \\
\text { towards management and supervision. }\end{array}$ \\
\hline
\end{tabular}

The survey included the following sections:

- Questions related to faculty demographics- Age, Gender, Education, and Program of Teaching;

- 29 items to measure the motivational needs of teachers teaching in higher educational institutions.

For data collection, relative to faculty feedback leading to faculty motivation, the respondents were asked to indicate their degree of satisfaction or dissatisfaction with each statement. The attribute items were measured on a 5-point Likert type scale of importance with 5 as 'Strongly Agree' to 1 as 'Strongly Disagree'.

- Sampling Design: The Universe of the study comprised all faculty members teaching in institutions of higher education in India. The Survey (Target) Population included all faculty members teaching in the Sahibzada Ajit Singh Nagar (Mohali) District, Punjab State, India who were willing to respond to the questionnaire and could be contacted on the days when the schedule was administered.

The Sampling design employed was non-probability Judgment and Convenience sampling and only the faculty members who were willing to respond were requested to respond to the questionnaire. 150 respondents comprised the final sample.

- Description of Sample: For the research, the data were collected by researchers from higher education institution faculty members. To obtain a profile of the respondents they were requested to complete questions regarding the following descriptive:

- Demographics: Gender, Age, Occupation (Profession), Education \& Income. The final sample consisted of 150 respondents. 


\begin{tabular}{|c|c|c|}
\hline \multicolumn{3}{|c|}{ Table 1: Overall Faculty Sample Frequencies } \\
\hline & & \\
\hline Descriptive & $\begin{array}{l}\text { Frequenc } \\
\mathbf{y}\end{array}$ & Percentage \\
\hline \multicolumn{3}{|l|}{ Age (in years) } \\
\hline Young (up to 35 years) & 88 & 59 \\
\hline Middle (36-60 years) & 62 & 41 \\
\hline Total & 150 & \\
\hline \multicolumn{3}{|l|}{ Gender } \\
\hline Male & 48 & 32 \\
\hline Female & 102 & 68 \\
\hline Total & 150 & \\
\hline \multicolumn{3}{|l|}{ Education Level } \\
\hline Post-graduation & 122 & 81 \\
\hline Doctorate & 28 & 19 \\
\hline Total & 150 & \\
\hline \multicolumn{3}{|l|}{ Program } \\
\hline Business Management & 37 & 25 \\
\hline Engineering & 70 & 47 \\
\hline Hotel Management & 26 & 17 \\
\hline Education & 17 & 11 \\
\hline Total & 150 & \\
\hline
\end{tabular}

Factor Analysis of Attributes Influencing Faculty Feedback and Motivation

The result of the factor analysis with Kaiser Normalization is given as per Table 2. The procedure short-listed 29 attributes influencing faculty feedback and motivation to move on to the next stage. The KMO score is above .50 (.835) and the Bartlett's test is significant $(\chi 2=2997.555, \mathrm{df}=406)$. Thus, factor analysis is suitable for this research (Malhotra \& Dash, 2009). The factors with an Eigenvalue more than 1 were retained. Six factors explainingr $71.776 \%$ (accounting for more than $50 \%$ of the total variance, Malhotra \& Dash, 2009) of the total variance were taken into consideration.

Table 2: Factors Influencing Faculty Feedback and Motivation

\begin{tabular}{|c|c|c|c|}
\hline & $\begin{array}{l}\text { Loadi } \\
\text { ng }\end{array}$ & $\begin{array}{l}\text { Eigen } \\
\text { value }\end{array}$ & $\begin{array}{l}\text { \% of } \\
\text { Variance }\end{array}$ \\
\hline Factor 1: Recognition & & 6.822 & 21.156 \\
\hline $\begin{array}{l}\text { Institution_contributes_to_my_recog } \\
\text { nition }\end{array}$ & 0.907 & & \\
\hline $\begin{array}{l}\text { Popular_for_professional_knowledg } \\
\text { e_and_competence }\end{array}$ & 0.888 & & \\
\hline People_respect_me_being_a_teacher & 0.86 & & \\
\hline $\begin{array}{l}\text { Job_is_in_harmony_with_expectatio } \\
\text { ns_of_people }\end{array}$ & 0.891 & & \\
\hline $\begin{array}{l}\text { Have_opportunities_to_broaden_pro } \\
\text { fessional_knowledge }\end{array}$ & 0.844 & & \\
\hline $\begin{array}{l}\text { People_in_institution_know_me_as__ } \\
\text { a_successful_worker }\end{array}$ & 0.87 & & \\
\hline $\begin{array}{l}\text { Job_helps_me_to_achieve_goals_in_ } \\
\text { life }\end{array}$ & 0.885 & & \\
\hline $\begin{array}{l}\text { Institution_gives_a_quality_educatio } \\
\text { n_based_on_learning }\end{array}$ & 0.801 & & \\
\hline Factor 2: Sense of Belongingness & & 5.423 & 20.398 \\
\hline Lots_of_friends_at_institution & 0.872 & & \\
\hline Peers_help_each_other & 0.857 & & \\
\hline Feel_at_home_in_workplace & 0.866 & & \\
\hline Can_use_creativity_in_institution & 0.885 & & \\
\hline Think_of_doing_job_properly & 0.852 & & \\
\hline $\begin{array}{l}\text { Institution_gives_opportunity_to_kn } \\
\text { ow_whether_I_do_job_well }\end{array}$ & 0.865 & & \\
\hline Hear_new_ideas_in_institution & 0.851 & & \\
\hline $\begin{array}{l}\text { Institution_adopt_democratic_partici } \\
\text { patory_approach }\end{array}$ & 0.784 & & \\
\hline Factor 3: Working Environment & & 3.497 & 9.781 \\
\hline $\begin{array}{l}\text { Superiors_do_not_try_to_block_adv } \\
\text { ancement }\end{array}$ & 0.699 & & \\
\hline Peers_do_not_try_to_damage_career & 0.79 & & \\
\hline $\begin{array}{l}\text { Consider_myself_equipped_for_teac } \\
\text { hing }\end{array}$ & 0.625 & & \\
\hline $\begin{array}{l}\text { Not_exposed_to_any_danger_of_hea } \\
\text { lth }\end{array}$ & 0.719 & & \\
\hline Job_security & 0.704 & & \\
\hline Factor 4: Basic Need Fulfilment & & 2.132 & 9.746 \\
\hline Meet_physiological_needs & 0.825 & & \\
\hline $\begin{array}{l}\text { Institution_provides_sufficient_reso } \\
\text { urces_to_do_job_better }\end{array}$ & 0.663 & & \\
\hline Institution_aids_continuous_learning & 0.834 & & \\
\hline Factor 5: Self Respect & & 1.846 & 6.788 \\
\hline $\begin{array}{l}\text { Respect_myself_for_profession_of_t } \\
\text { eaching }\end{array}$ & 0.727 & & \\
\hline Teaching_is_an_ideal_job_for_me & 0.623 & & \\
\hline $\begin{array}{l}\text { Teaching_makes_my_life_more_me } \\
\text { aningful }\end{array}$ & & & \\
\hline
\end{tabular}




\begin{tabular}{|c|c|c|c|}
\hline Job_gives_me_freedom_and_power & 0.863 & & \\
\hline \multicolumn{4}{|l|}{ Factor 6: Contribution to Society } \\
\hline $\begin{array}{l}\text { Job_contributes_to_development_of } \\
\text { _society_and_state }\end{array}$ & 0.925 & 1.095 & 3.906 \\
\hline \multicolumn{4}{|c|}{ Extraction Method: Principal Component Analysis. } \\
\hline
\end{tabular}

Based on these dimensions, innovative ways such as motivating faculty members to learn business skills to manage teaching profession-related activities economically and effectively i.e. faculty feedback and motivation has been analyzed.

\section{ANALYSIS AND DISCUSSIONS}

In higher education faculty feedback and motivation, reforms in education, psychological fulfilment and well-being of teachers and teaching practice also play crucial role (J. Han and H. Yin, 2016) Keeping this in view 'Happy Teachers, Better Students', the 'Ways to Increase Teacher Motivation' (Catchbox) have been mentioned below:

\section{Give Teachers Autonomy}

\section{Allow Collaboration}

\section{Offer Recognition and Respect}

Some commonality of attributes between faculty feedback and motivation is observed. The major attributes influencing faculty feedback and motivation that have emerged from this study (Table 2) helped in determining the attitude of faculty towards satisfaction for imparting better higher education. The evaluation of measured attitude of faculty ultimately converged into six major Dimensions of Recognition, Sense of Belongingness, Working Environment, Basic Need Fulfillment, Self Respect and Contribution to Society for imparting better higher education.

Here, a brief overview of select factors influencing faculty satisfaction is given based on the findings of the research:

Important Factors Influencing Faculty Satisfaction:

\section{Recognition:}

To be an effective faculty, the first question is 'which factors motivate to maximum'? Being high risk involved, a person must seek mentorship from experienced dignitaries in the field. They will provide insight into carrying out activities in most effective ways. They will also provide guidance about inculcating various skills. Faculty members strive for recognition. They work much beyond Institution Hours, work from home, work at home, contribute passionately, but their efforts remain unrewarded or unrecognized. An appreciation for a person's job leads to a positive or pleasant emotional state i.e. job satisfaction (Z. Demirtas, 2010).

\section{Sense of Belongingness:}

One-third of the day is spent by faculty at the workplace. They consider the workplace their second home and work selflessly and heartily. Both public and private sector universities and colleges should be kept free from political interference (M, Ahmad, University World News, 08 February 2019).

\section{Working Environment:}

Teachers need a high level of concentration so as to gain knowledge and plan to deliver it in a way that it goes straight in the minds of the learners in the same way as has been desired. Some balance has to be maintained by increasing the fund allocation (M, Ahmad, University World News, 08 February 2019). The efforts put in by a teacher for preparation of an effective lesson plan will get reflected in the personality of each and every student he/ she has come across.

\section{Basic Need Fulfillment:}

The major trauma for faculty members, especially the head of the families is lack of job security despite working for decades in a particular institute in private sector. "Quality of many universities and colleges and the standard of education they provide are far from satisfactory" (National Education Policy Draft Report by TSR Subramanian). An estimated $40 \%$ of college teachers work on a non-permanent, ad hoc basis and are designated variously as temporary, contractual, ad hoc and guest faculty. (M, Ahmad, University World News, 08 February 2019).

\section{Self Respect}

As mentioned above, Autonomy must be given to teachers. But, for the sake of promotion, even the older and experienced faculty members are bound to publish a minimum number of papers every year. The emphasis is more on publishing papers than on teaching. As a result, they focus on publishing papers in journals but not on high-quality journals. Also, some colleges lack basic and high-end research facilities (M, Ahmad, University World News, 08 February 2019).

\section{Contribution to Society}

o My job contributes to the development of society and the state.

For effective contribution towards society, parents of students must also be imparted education. In India, the basis of choosing a particular program is the expected attractive high package, rather than area of interest. Some colleges even do not have basic facilities and are like teaching workshops for postgraduate students (M, Ahmad, University World News, 08 February 2019)

We need to focus only on universities with faculty of high standing out of numerous universities (M, Ahmad, University World News, 08 February 2019).

\section{CONCLUSION}

Ultimately, positive feedback of faculty leads to higher and continuous motivational levels, which will contribute to developing bright students in the future. The respondents include only those faculty members who were willing to respond. The exploratory study was conducted in Mohali, Punjab, India; the faculty' perceptions and attitude might vary in other regions. The findings of the study provide the basis for further research to be carried out in the same field with larger sample size, larger area, might be expanded across the boundaries. 


\section{ACKNOWLEDGMENT}

We are thankful to the management for providing us the vision, resources and full support to conduct the research. We are also thankful to respondents for their invaluable contribution. Last, but not least, we are thankful to Almighty for the opportunity as well as family, friends, and peers for their untimely support to give the shape to the research.

\section{REFERENCES}

[1] Dr. K. Nigama, Dr. S. Selvabaskar, Dr. S. T Surulivel, Dr. R. Alamelu and Ms. D. Uthaya Joice (2018). Job satisfaction among school teachers, International Journal of Pure and Applied Mathematics, vol. 119(7), special issue, pp. 2645-2655.

[2] J. Han and H. Yin (2016), Teacher motivation: Definition, research development and implications for teachers, Cogent Education, 3: 1217819, pp. 1-18.

[3] V. Ramachandran and M. Pal, Dr. S. Jain, S. Shekar, J. Sharma (2005).Teacher Motivation in India, pp. 1-38.

[4] World Development Report (2018), Teacher skills and motivation both matter (though many education systems act like they don't), pp. 131-139.

[5] F. Gokce (2010). Assessment of teacher motivation. School Leadership and Management, 30(5), pp. 487-499.

[6] India Brand Equity Foundation (IBEF) Report, April 2019. Education and training industry in India.

[7] India Brand Equity Foundation (IBEF) Report, June 2018. Education and training report.

[8] 12 Skills teachers require to be effective in teaching. 12 February 2018. https://www.edsys.in/8-skills-teachers-require-effectiveteaching/

[9] Z. Ozguner and M. Ozguner (June 2014). A managerial point of view on the relationship between Maslow's hierarchy of needs and Herzberg's dual factor theory, International Journal of Business and Social Science, vol. 5(7), pp. 207-215.

[10] Z. Demirtas (2010). Teachers' job satisfaction levels, Procedia Social and Behavioral Sciences 9, pp. 1069-1073.

[11] M. I. Rasheed, A. A. Humayon, U. Awan and A-ud-D. Ahmed (2016). Factors affecting teachers' motivation, International Journal of Educational Management, vol. 30(1), pp. $101-114$

[12] C. M. Calkins (2018). Developing and Measuring Faculty Motivation to Teach in Higher Education. UNLV Theses, Dissertations, Professional Papers, and Capstones. 3227, pp. 1-154.

[13] S. Munyengabe, H. Haiyan, Z. Yiyi and S. Jiefei (2017). Factors and levels associated with lecturers' motivation and job satisfaction at a Chinese University. EURASIA J Math Sci and Tech Ed., vol. 13(10), pp. 6415-6430.

[14] H. U. Amin and A. R. Khan (2009). Acquiring Knowledge for Evaluation of Teachers' Performance in Higher Education - using a Questionnaire, International Journal of Computer Science and Information Security, vol. 2(1).
[15] M, Ahmad (08 February 2019). What is wrong with the Indian higher education system? University World News. https://www.universityworldnews.com/post.php?story=2 $\underline{0190129125036113}$

[16] Happy Teachers, Better Students: Three Ways to Motivate Your Teachers and Your Engage Students. https://catchbox.com/education/teacher-motivation/

\section{AUTHORS PROFILE}

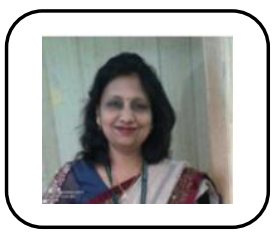

Dr. Monika Gupta Vashisht is currently serving as Associate Professor, Chandigarh Business School of Administration, Chandigarh Group of Colleges, Landran-Mohali and has previously served with corporates Nilkamal Group, Amartex Industries Ltd and others for more than 4 years. She has earned Ph.D degree in Management from Maharishi Markandeshwar University, Mullana-Ambala. She is also UGC-NET qualified in Management. She has more than 15 years of academic and corporate experience. Her areas of interest are Marketing Management, Service Marketing, Retail Marketing, Advertising Management, Consumer Behaviour, Strategic Management and Foundations of Management. She has written 21 research papers and 6 book reviews in International and National Journals and Conference Proceedings. She has also organized National Conferences. She is 'Circulation Editor' of UGC listed International Journal 'Biz and Bytes' (Print ISSN: 2320-897X \& E-ISSN: 0976-0458). She also remained 'Editor' of UGC listed International Journal 'GGGI Management Review' (ISSN 2249-4103). She is also 'Associate Editor' of Newletter 'Reflectionz'. She has 'Lifetime Membership' of 'The Society for Management Education' (TSME), Kurukshetra since 2012. Besides, she is coordinating various departmental activities of high responsibility.

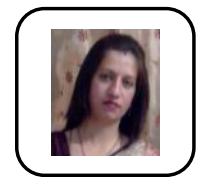

Ashima Kalra , Gold Medalist in B Tech in Electronics from Kurukshetra University, Kurukshetra in 2003 Received M.Tech degree from Punjab Technical University, Kapurthla (Punjab)in 2008 and pursuing PhD from Punjab Technical University, Kapurthla (Punjab )in the field of soft Computing. She has published more than 25 papers in reputed journals and 3 book chapters in Springer series. Her research activities include designing model identification using neural networks, fuzzy systems, supervised learning .machine learning. Lifetime IEEE member and has been serving as a fellow member of IEEE Delhi section, India. Organized 3 IEEE international conferences as a chairperson.

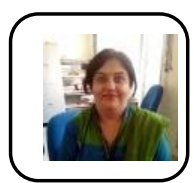

Dr. Bhawna Tandon received her BTech in Electronics and Instrumentation in 2001, ME in Instrumentation and Control in 2009 and $\mathrm{PhD}$ in Control System from Kurukshetra University, Kurukshetra, Panjab University, Chandigarh and PEC (Deemed to be University) Chandigarh respectively. She is having teaching experience of 17 Years and currently working as an Associate Professor at Chandigarh Engineering College, Landran, Mohali. She is having more than 20 research publications in reputed International journals. Her current research interests include robust control, non-linear control and optimisation techniques. 